\title{
CES2 wt Allele
}

National Cancer Institute

\section{Source}

National Cancer Institute. CES2 wt Allele. NCI Thesaurus. Code C116038.

Human CES2 wild-type allele is located in the vicinity of $16 q 22.1$ and is approximately 11 $\mathrm{kb}$ in length. This allele, which encodes cocaine esterase protein, plays a role in the catabolism of xenobiotics. 